\title{
Rancang Bangun Mesin Pemasang Snap Ring untuk Mengurangi Cycle Time pada Assembling Transmission FF di PT. AWI
}

\author{
Timotius Anggit Kristiawan*, Zaenal Abidin, Panji Setya Laksono, Wahyu Isti Nugroho \\ Program Studi Sarjana Terapan Teknik Mesin Produksi dan Perawatan \\ Jurusan Teknik Mesin Politeknik Negeri Semarang \\ Jl. Prof. H. Soedarto, S.H., Tembalang, Kota Semarang, Jawa Tengah 50275
}

*Email: anggit.kristiawan@polines.ac.id

Diterima: 01-03-2021; Direvisi: 29-03-2021; Dipublikasi: 27-04-2021

\begin{abstract}
Abstrak
Sejalan dengan tujuan pemerintah untuk mewujudkan Indonesia sebagai negara industri yang tangguh pada tahun 2025, perlunya dukungan terhadap industri komponen otomotif dalam proses produksi untuk memenuhi kubutuhan dalam negeri. Latar belakang penelitian ini adalah target cycle time pada assembling transmission FF tidak tercapai (melebihi target waktu yang ada di TSK PT. Akashi Wahana Indonesia), dikarenakan terdapat proses pemasangan snap ring yang masih manual. Penyebabnya adalah proses pemasangan snap ring dilakukan secara manual menggunakan tenaga manusia dimana proses pemasangannya menggunakan tuas yang tinggi yaitu sejajar dengan bahu operator serta dalam satu shift kerja harus memasang snap ring pada 495 produk. Pemasangan dengan cara ini dimungkinkan mengakibatkan kelelahan pada operator, karena posisi tuas yang kurang ergonomis. Data aktual cycle time assembling transmission $F F$ sebesar 98,015 detik, adapun TSK assembling transmission $F F$ sebesar 96 detik. Berdasarkan permasalahan tersebut maka perlu adanya solusi yaitu dengan membuat rancang bangun mesin press pneumatik semi otomatis berbasis PLC untuk pemasangan snap ring pada input shaft gear dan mengurangi cycle time pada assembling transmission FF line. Pengujian yang dilakukan yaitu pengujian cycle time pada assembling transmission $F F$. Hasil yang diperoleh dari penelitian ini adalah mesin press pneumatik untuk pemasangan snap ring dapat mengurangi cycle time sebesar $3,48 \%$.
\end{abstract}

Kata kunci: assembling transmission; cycle time; mesin press; pneumatik

\begin{abstract}
In line with the government's goal of realizing Indonesia as a strong industrialized country by 2025, it is necessary to support the automotive component industry in the production process to meet domestic needs. The background of this research is that the target cycle time in the FF transmission assembly has not been achieved (it exceeds the target time in TSK PT. Akashi Wahana Indonesia), because there is a installation process of snap ring that is still manual. The reason is that the installation process of snap ring is carried out manually using human labor, where the installation process uses a high lever parallel to the shoulder operator and in one working shift must install sanp rings on 495 products. Installation in this way allows control of the operator, due to the less ergonomic position. Actual data cycle time assembling FF transmission is 98.015 seconds, while TSK assembling FF transmission is 96 seconds. Based on these problems, it is necessary to have a solution, namely by designing a semi-automatic pneumatic press machine based on PLC for installing snap rings on the input shaft gear and reducing cycle times in the assembling transmission FF line. The test carried out is testing the cycle time on the FF transmission assembly. The results obtained from this study are the pneumatic press machine for snap ring installation can reduce cycle times by $3.48 \%$.
\end{abstract}

Keywords: assembling transmission; cycle time; press machine; pneumatic

\section{Pendahuluan}

Sejalan dengan tujuan pemerintah untuk mewujudkan Indonesia sebagai negara industri yang tangguh pada tahun 2025, dan mengacu pada tiga misi utama industri nasional yaitu: 1) pertumbuhan ekonomi di atas 7\%,2) peningkatan daya tarik investasi dan daya saing bangsa, dan 3) penciptaan lapangan kerja dan penurunan angka kemiskinan maka terdapat 10 klaster industri yang akan dikembangkan sesuai dengan perannya. Industri otomotif dan komponen otomotif 
(Kamar Dagang dan Industri Indonesia 2010) merupakan salah satu klaster industri unggulan yang berperan mendongkrak pertumbuhan ekonomi di atas 7\% [1]. Dalam mendukung terpenuhinya komponen industri otomotif dalam negeri perlunya dukungan dalam proses produksi komponen otomotif di industri-industri yang ada di Indonesia melalui kerjasama industri. Salah satu strategi pengembangan inovasi dan kerjasama industri yang dapat dilakukan adalah adanya sinergi program kerjasama penelitian dan pengembangan antara lembaga riset pemerintah, lembaga riset swasta, perguruan tinggi dan dunia usaha [2].

Setiap proses produksi pasti membutuhkan waktu siklus yang disebut dengan cycle time. Cycle time adalah keseluruhan waktu yang diperlukan untuk mengolah bahan baku menjadi produk jadi [3]. Sesuai dengan TSK (Tabel Standarisasi Kerja) PT. Akashi Wahana Indonesia, proses assembling transmission FF membutuhkan cycle time sebesar 96 detik/unit, namun kondisi aktualnya membutuhkan waktu 98 detik/unit (1,8\% lebih besar dari cycle time target di PT. Akashi Wahana Indonesia). Pada line transmisi FF terdapat beberapa mesin yang berguna untuk mendukung proses assembling transmission FF (tipe D55C, D21N, dan D30N), salah satunya yaitu proses pemasangan snap ring pada input shaft gear. Fungsi snap ring pada proses ini adalah sebagai pengunci roller bearing agar tidak lepas. Salah satu permasalahan yang dihadapi pada proses assembling transmission $F F$ yaitu proses pemasangan snap ring masih dilakukan secara manual dan peralatan yang digunakan kurang memenuhi standar ergonomi kerja. Proses pemasangan snap ring dilakukan secara manual yaitu dengan menggunakan tuas yang ditarik oleh operator. Alat bantu proses pemasangan snap ring yang digunakan kurang ergonomis dikarenakan tinggi posisi tuas sejajar dengan bahu operator dengan proses kerja satu shift memasang snap ring pada 495 produk. Ergonomi dipandang sebagai disiplin ilmu yang mempelajari manuasia dalam kaitannya dengan pekerjaan, merancang suatu sistem kerja sehingga orang dapat hidup dan bekerja pada sistem tersebut dengan baik [4]. Dampak dari permasalahan tersebut adalah operator mengalami kelelahan, dan proses waktu pemasangan snap ring mengalami penurunan sehingga cycle time meningkat. Cycle time dapat dikurangi dengan manajemen permintaan yang tepat. Menurut Wavhal dkk. [5] Komunikasi yang tepat antara berbagai departemen terkait, waktu idle antara dua operasi berturut-turut berkurang dan pada akhirnya mengurangi cycle time. Ismail [6] dalam penelitiannya menganalisa proses pengemasan pada suatu industri dengan menggunakan line balancing dalam upaya peningkatan efisiensi dan output, perbaikan produktivitas dan efisiensi proses pengemasan dilakukan untuk menghasilkan cycle time yang lebih baik dimana data perbandingan sebelum dan sesudah improvement menujukkan pengurangan cycle time.

Menurut Dutt [7], pneumatik adalah bagian dari teknologi yang berhubungan dengan studi dan aplikasi gas bertekanan untuk menghasilkan gerakan mekanis. Pemilihan penggunaan sistem pneumatik sebagai tenaga penggerak dalam mesin press snap ring, dikarenakan sistem pneumatik sudah digunakan secara luas dalam industri, dan pabrikpabrik biasanya diselami dengan udara terkompresi atau gas inert terkompresi. Hal ini dikarenakan kompresor yang terletak dipusat dan bertenaga listrik yang menggerakkan silinder dan perangkat pneumatik lainnya melalui katup solenoid sering kali dapat menyediakan daya motif dengan cara yang lebih murah, lebih aman, lebih fleksibel, dan lebih handal dari pada sejumlah besar motor dan aktuator listrik. Setiawan dkk. [8] dalam penelitian rancang bangun mesin press briket menggunakan sistem pneumatik sebagai tenaga penggeraknya, pemilihan tersebut dikarenakan ketersediaan udara yang tidak terbatas, mudah disalurkan, fleksibilitas, temperatur, aman, bersih, pemindahan daya dan kecepatan yang mudah di atur. Hudallah [9] menyatakan selain akurat sistem pneumatik juga cukup andal, aman dan awet. Penggunaan pneumatik dengan kontrol PLC untuk perancangan mesin snap ring dengan mengubah udara terkompresi menjadi gerakan translasi yang mendorong snap ring dapat terpasang pada input shaft gear dengan baik sehingga proses pemasangan manual dari tuas dengan tenaga dari manusia (operator) dapat dihilangkan. 
Timotius Anggit Kristiawan dkk /Jurnal Rekayasa Mesin

p-ISSN: 1411-6863, e-ISSN: 2540-7678

Vol.16|No.1|39-47|April|2021

Tujuan dari penelitian ini adalah membuat rancang bangun mesin press untuk memberikan pemecahan masalah (problem solving) berupa inovasi atau improvement pada proses pemasangan snap ring secara semi otomatis menggunakan sistem pneumatik sebagai tenaga penggeraknya, sehingga mampu menurunkan cycle time sesuai dengan TSK (Tabel Standarisasi Kerja) PT. Akashi Wahana Indonesia dan mengurangi kelelahan operator di assembling transmission FF PT. Akashi Wahana Indonesia.

\section{Material dan metodologi}

\subsection{Root Cause Analysis (RCA)}

Root Cause Analyis (RCA) adalah sebuah proses dirancang untuk digunakan dalam penyelidikan dan pengelompokan akar penyebab peristiwa dengan aman, kesehatan, lingkungan, kualitas, keandalan dan dampak produksi. Secara sederhana, RCA adalah alat yang dirancang untuk membantu mengidentifikasi tidak hanya apa dan bagaimana suatu peristiwa terjadi, tetapi juga mengapa itu terjadi [10]. Untuk menyelesaikan masalah, seseorang harus mengidentifikasi penyebab masalah dan mengambil langkah-langkah untuk menghilangkan penyebabnya. Jika akar masalah tidak teridentifikasi, lalu satu hanyalah mengatasi gejala dan masalahnya akan terus ada. Untuk alasan ini, identifikasi dan menghilangkan akar penyebab masalah $(R C A)$ adalah yang terpenting dan terbaik [11]. Vorley [12] menyatakan bahwa untuk menyelesaikan masalah dengan metode RCA menggunakan 5 langkah dasar yaitu identify the problem, define the problem, understand the problem, identify the root cause, corrective action, dan monitor the sistem.

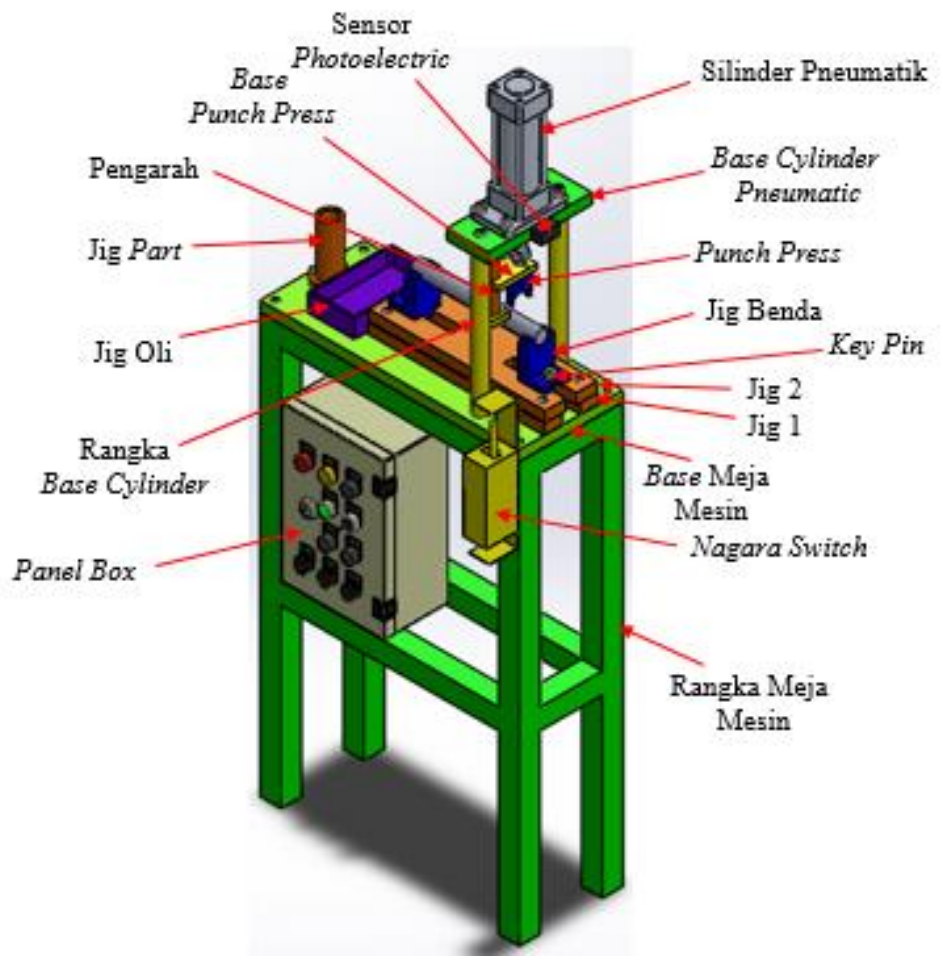

Gambar 1. Desain \& Komponen Mesin

\subsection{Desain Mesin Press Snap ring}

Proses pembuatan desain ini dilakukan dengan menggunakan software solidworks. Desain dan komponenkomponen mesin press snap ring semi otomatis dapat dilihat pada Gambar 1. Mekanisme kerja mesin press snap ring untuk memasang snap ring menggunakan tenaga pneumatik sebagai tenaga penggeraknya \& PLC sebagai kontrolernya. 
Ketika nagara switch ditekan maka akan menggerakan silinder pneumatik ke bawah sehingga snap ring terpasang dengan sempurna, kemudian silinder bergerak kembali ke atas.

\subsection{Pembuatan Mesin}

Proses pembuatan rancang bangun dilakukan di PT. Akashi Wahana Indonesia. Proses pengerjaan membutuhkan waktu selama kurang lebih 1 bulan. Gambar 2 menjelaskan tentang diagram proses pembuatan alat di workshop PT. Akashi Wahana Indonesia Departemen Production Engineering assembling Transmission \& Workshop.

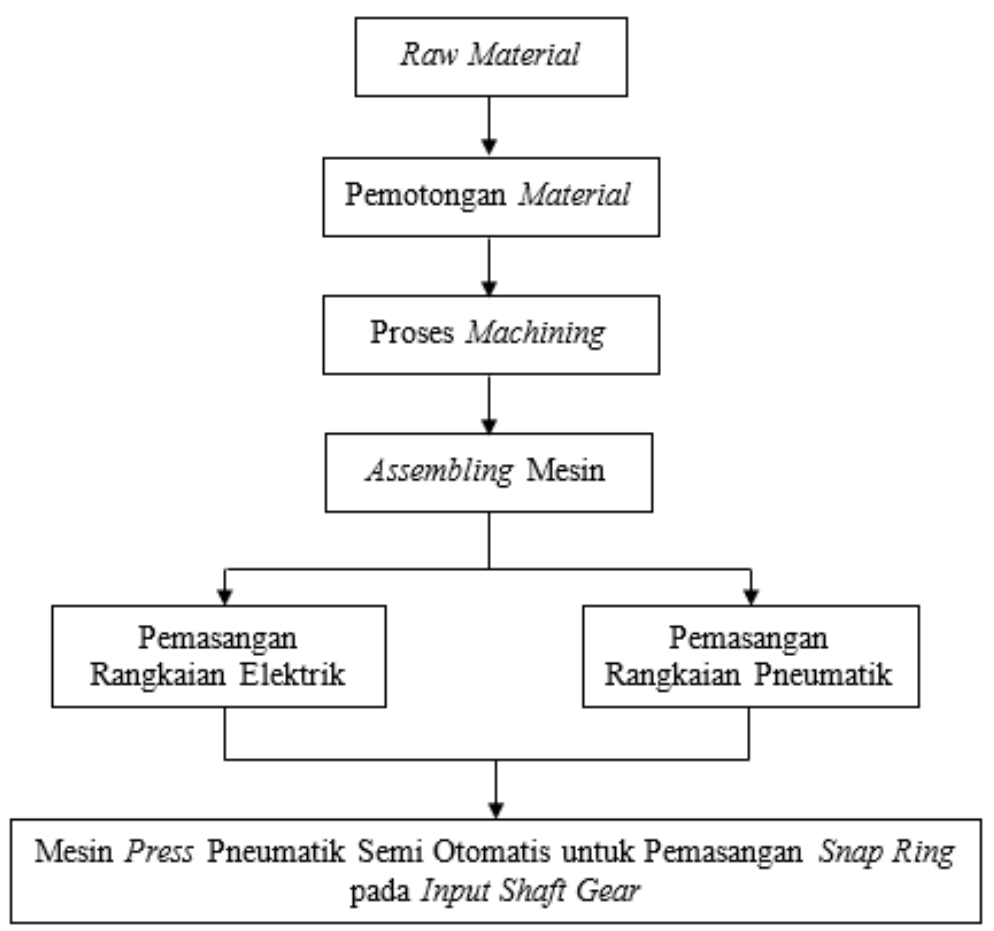

Gambar 2. Diagram Proses Pembuatan mesin press snap ring semi otomatis

Material yang digunakan untuk membuat meja mesin, jig 1, jig 2, base silinder pneumatik, dan base punch press adalah AISI 1010. Material yang digunakan untuk membuat rangka, key pin, pengarah, dan punch press adalah AISI 1045. Material yang digunakan untuk membuat jig oli, jig part, dan jig benda adalah MC 904 nylon blue. Rangka mesin press snap ring dibuat dari material besi hollow ASTM A36. Pemotongan material di workshop PT. Akashi Wahana Indonesia menggunakan plasma cutting machine dan grinding cutting machine. Permesinan untuk membuat komponen mesin press pneumatik semi otomatis dilakukan dengan tiga mesin seperti terlihat pada Gambar 3. Tiga mesin tersebut yaitu:

1. CNC turning machine, untuk membuat meja mesin, jig 1, jig 2, jig oli, base silinder pneumatik, dan base punch press.

2. CNC milling machine, untuk membuat rangka, key pin, pengarah, punch press, jig part, dan jig benda.

3. Surface grinding machine, digunakan sebagai proses finishing setelah dilakukan machining pada komponen meja mesin, jig 1, jig 2, base silinder pneumatik, dan base punch press. 


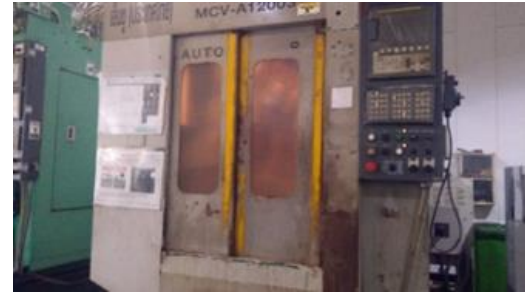

(a)

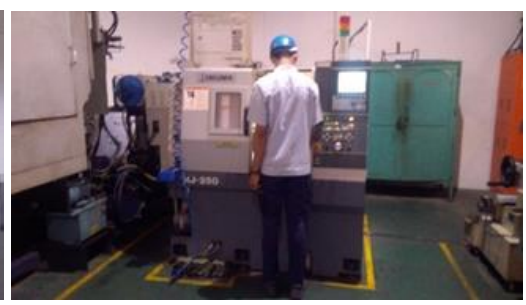

(b)

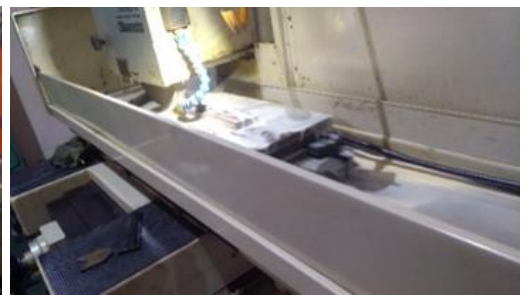

(c)

Gambar 3. (a) CNC Milling Machine (b) CNC Turning Machine (d) Surface Grinding Machine

Semua komponen di assembling dengan menggunakan baut L (socket head cap screw). Baut L yang dibutuhkan untuk assembling mesin adalah M5 x 15 sebanyak 5 pcs, M6 x 20 sebanyak 2 pcs, M8 x 20 sebanyak 18 pcs, dan M12 x 30 sebanyak 4 pcs. PLC digunakan sebagai kontrol mesin press snap ring. Kadirun dkk. [13] menyatakan alasan utama perancangan PLC adalah untuk menghilangkan beban ongkos perawatan dan penggantian sistem kontrol mesin berbasis relay. Rangkaian elektrik dan PLC dipasang pada panel box, dan antar komponen dihubungkan dengan kabel sesuai dengan sistem kerja mesin. Silinder yang digunakan pada mesin tersebut adalah double acting cylinder SMC MBF 63100. Solenoid valve yang digunakan pada mesin tersebut adalah solenoid tipe $5 / 3$ way. Kedua komponen tersebut dihubungkan dengan menggunakan selang $\varnothing 6 \mathrm{~mm}$. Proses akhir pembuatan mesin yaitu pemasangan rangkaian elektrik dan rangkaaian pneumatik pada mesin.

\subsection{Pengujian Cycle time}

Pengujian cycle time dilakukan dengan membandingkan waktu proses pemasangan snap ring sebelum dan setelah menggunakam mesin snap ring semi otomatis. Prosedur pengujian cylcle time tersaji pada Gambar 4. Berdasarkan Gambar 4, proses pengujian dimulai dengan mempersiapkan semua alat dan bahan yang dibutuhkan, seperti menyiapkan input shaft gear, snap ring, stopwatch, dan mesin yang akan diuji.

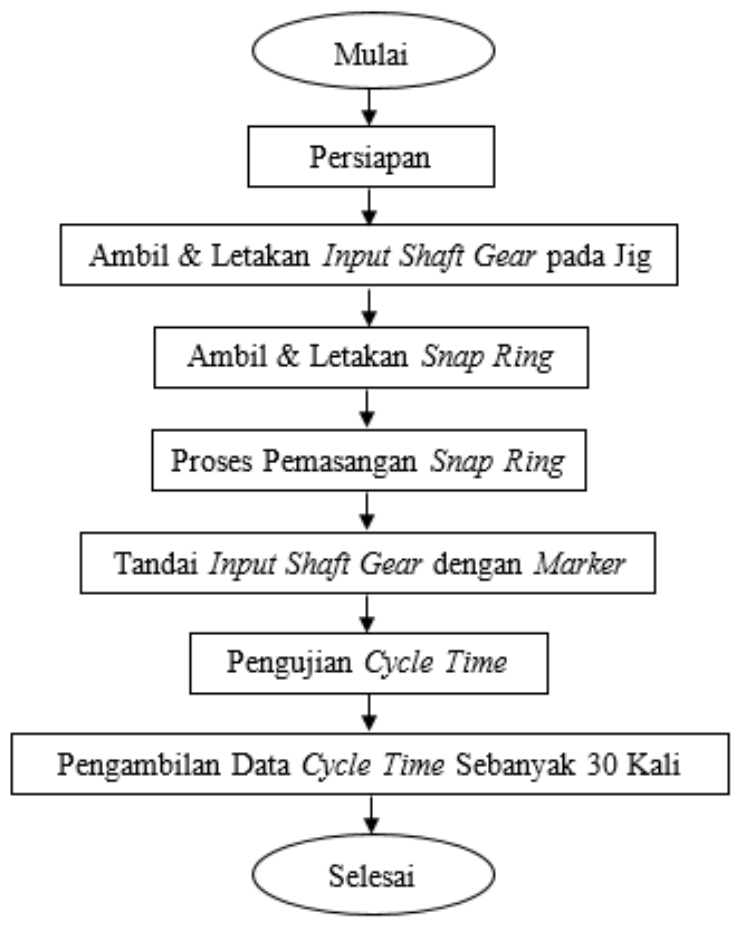

Gambar 4. Prosedur Pengujian Cycle time 
Timotius Anggit Kristiawan dkk /Jurnal Rekayasa Mesin

p-ISSN: 1411-6863, e-ISSN: 2540-7678

Vol.16|No.1|39-47|April|2021

Langkah pengujiannya yaitu: menghubungkan panel box dengan stop kontak, kemudian menyalakan tombol power yang ada di panel box, mengambil input shaft gear dan meletakkan pada jig mesin, dilanjutkan dengan mengambil snap ring dan meletakkan pada alur snap ring yang ada di input shaft gear. Untuk melakukan pemasangan snap ring secara semi otomatis dengan menekan tombol pada nagara switch, proses selanjutnya adalah menandai input shaft gear dengan menggunakan marker. Mencatat waktu dari mulai meletakan input shaft gear sampai dengan menandai input shaft gear dengan menggunakan marker, kemudian dikombinasikan waktu pada assembling sub assy input \& output shaft gear. Data pengujian cycle time dilakukan sebanyak 30 kali.

\section{Hasil dan pembahasan}

\subsection{Perwujudan Mesin}

Setelah dilakukan permesinan \& assembly, gambar realisasi mesin press pneumatik semi otomatis untuk pemasangan snap ring pada input shaft gear tersaji pada Gambar 5.

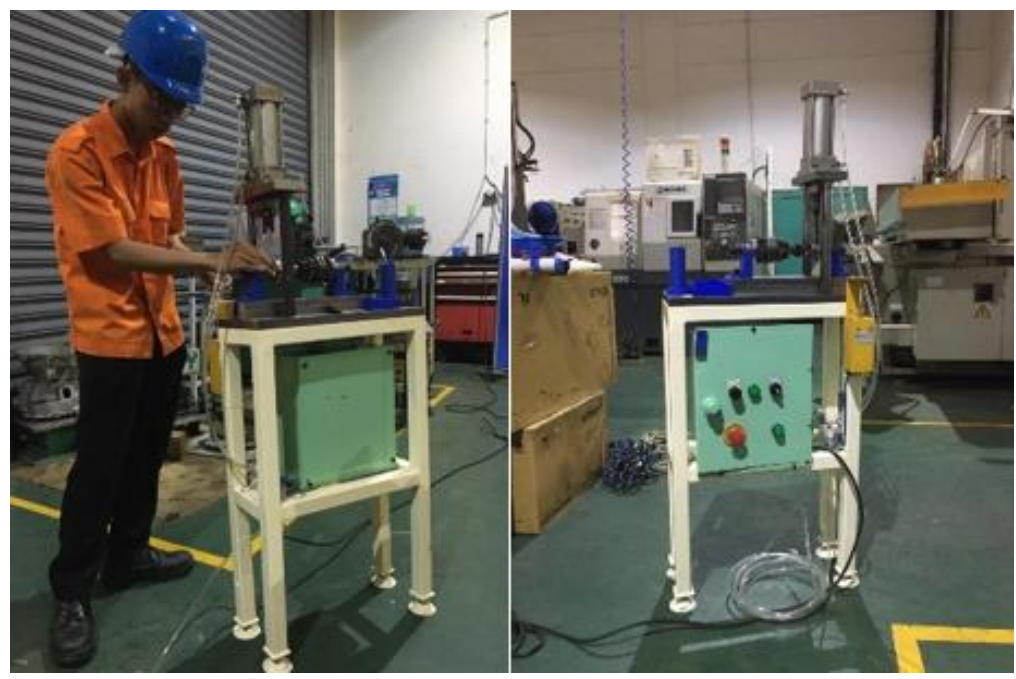

Gambar 5. Realisasi mesin Press Pneumatik Semi Otomatis untuk Pemasangan Snap ring

\subsection{Monitor the System}

Pada saat trial \& error, mesin tidak dapat melakukan pemasangan snap ring. Hal ini dikarenakan diameter punch press sama dengan diameter luar dari snap ring, ketika mesin dijalankan (di press) snap ring tidak bisa mengembang, sehingga snap ring gagal dipasang. Solusi dari permasalahan tersebut adalah dengan memperbesar diameter punch press dari $30 \mathrm{~mm}$ menjadi $35 \mathrm{~mm}$ (Gambar 6).

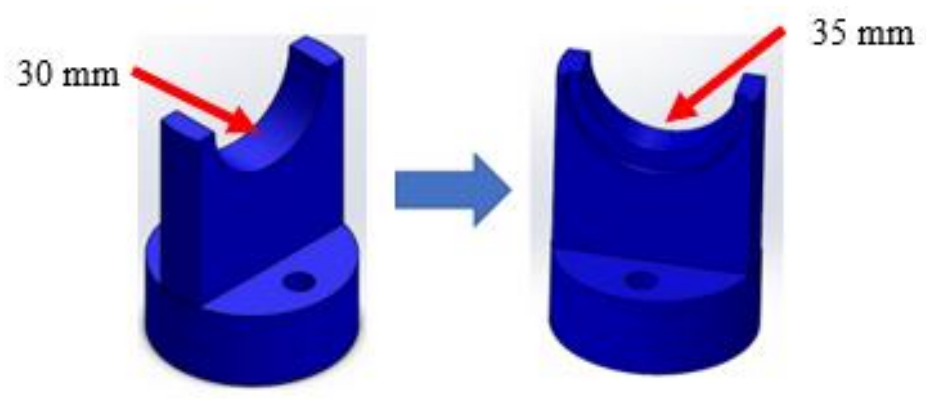

Gambar 6. Perbesaran Diameter Punch Press 
Timotius Anggit Kristiawan dkk /Jurnal Rekayasa Mesin

p-ISSN: 1411-6863, e-ISSN: 2540-7678

Vol.16|No.1|39-47|April|2021

\subsection{Analisis Statistik Metode Paired T Test}

Berdasarkan hasil data pengujian sebelum dan sesudah improvement dengan mesin snap ring semi otomatis seperti yang ditunjukkan pada Tabel 1, dengan tekanan saat pengujian sebesar 0,4[MPa] sesuai dengan tekanan standar setiap line yang ada di PT. Akashi Wahana Indonesia. Kedua data tersebut selanjutnya akan dilakukan analisis statistik menggunakan software SPSS 26 metode paired sampel t-test. Menurut Chriestie dkk. [14] paired t-test merupakan salah satu metode pengujian hipotesis dimana data yang digunakan tidak bebas (berpasangan). Dengan demikian uji ini dimaksudkan untuk menguji perbedaan antara sebelum dan sesudah diberikan treatment tertentu [15].

Tabel 1. Data waktu proses sebelum dan sesudah menggunakan mesin snap ring semi otomatis

\begin{tabular}{ccccccccccccccccccc}
\hline $\begin{array}{c}\text { Percobaan } \\
\text { Ke }\end{array}$ & $\mathbf{1}$ & $\mathbf{2}$ & $\mathbf{3}$ & $\mathbf{4}$ & $\mathbf{5}$ & $\mathbf{6}$ & $\mathbf{7}$ & $\mathbf{8}$ & $\mathbf{9}$ & $\mathbf{1 0}$ & $\mathbf{1 1}$ & $\mathbf{1 2}$ & $\mathbf{1 3}$ & $\mathbf{1 4}$ & $\mathbf{1 5}$ \\
\hline $\begin{array}{c}\text { Sebelum } \\
\text { (detik) }\end{array}$ & 98,5 & 97 & 98 & 99,5 & 97 & 97,75 & 98 & 98 & 98,3 & 99,1 & 97,98 & 97,13 & 97,45 & 98 & 99 \\
\hline $\begin{array}{c}\text { Sesudah } \\
\text { (detik) }\end{array}$ & 94,2 & 94,15 & 94,3 & 94,6 & 94,02 & 94,85 & 94,74 & 94,8 & 94,45 & 95,1 & 94,2 & 95,1 & 94,2 & 95 & 94,6 \\
$\begin{array}{c}\text { Percobaan } \\
\text { Ke }\end{array}$ & $\mathbf{1 6}$ & $\mathbf{1 7}$ & $\mathbf{1 8}$ & $\mathbf{1 9}$ & $\mathbf{2 0}$ & $\mathbf{2 1}$ & $\mathbf{2 2}$ & $\mathbf{2 3}$ & $\mathbf{2 4}$ & $\mathbf{2 5}$ & $\mathbf{2 6}$ & $\mathbf{2 7}$ & $\mathbf{2 8}$ & $\mathbf{2 9}$ & $\mathbf{3 0}$ \\
\hline $\begin{array}{c}\text { Sebelum } \\
\text { (detik) }\end{array}$ & 97,5 & 98,6 & 97,1 & 97,8 & 97,9 & 98,25 & 98 & 99,3 & 97,5 & 96,94 & 96,9 & 96,83 & 98,5 & 97,53 & 99,4 \\
\hline $\begin{array}{c}\text { Sesudah } \\
\text { (detik) }\end{array}$ & 95,35 & 94,65 & 95,1 & 94,8 & 94,32 & 94,25 & 94 & 94,35 & 94,5 & 94,94 & 94,9 & 94,8 & 94,55 & 94 & 95,4 \\
\hline
\end{tabular}

Setelah data terkumpul (sebagaimana data di atas) selanjutnya adalah melakukan uji beda 2 rata-rata antara sampel berpasangan (paired sample t-tes) untuk mengetahui apakah terdapat perbedaan nilai tes antara sebelum dan sesudah adanya mesin press pneumatik untuk pemasangan snap ring. Pengujian menggunakan tingkat signifikansi 0,05 atau tingkat kepercayaan sebesar $95 \%$. Hipotesis yang digunakan adalah:

Ho : tidak terdapat perbedaan rata-rata proses pemasangan snap ring sebelum dan sesudah adanya mesin press pneumatik untuk pemasangan snap ring.

$\mathrm{Ha} \quad$ : terdapat perbedaan rata-rata proses pemasangan snap ring sebelum dan sesudah adanya mesin press pneumatik untuk pemasangan snap ring sehingga berpengaruh pada penurunan cycle time di assembling transmission $F F$.

Hasil pengolahan SPSS dengan metode paired sample t-test ditunjukkan pada Gambar 7.

\section{Paired Samples Test}

Pair 1

Sebelum -

Sesudah

\begin{tabular}{lllr}
\hline Paired & Mean & & 3,35133 \\
\cline { 2 - 4 } Differences & Std. Deviation & &, 85923 \\
\cline { 2 - 4 } & Std. Error Mean & &, 15687 \\
\cline { 2 - 4 } & $\begin{array}{l}\text { 95\% Confidence } \\
\text { Interval of the }\end{array}$ & Lower & 3,03049 \\
\cline { 2 - 3 } & Difference & 3,67217 \\
\hline $\mathrm{t}$ & & & \\
\hline df & & 21,363 \\
\hline Sig. (2-tailed) & & 29 \\
\hline
\end{tabular}

Gambar 7. Hasil Pengolahan Data dengan SPSS 
Timotius Anggit Kristiawan dkk /Jurnal Rekayasa Mesin

p-ISSN: 1411-6863, e-ISSN: 2540-7678 Vol.16|No.1|39-47|April|2021

Menggunakan nilai kepercayaan sebesar 95\% dan nilai standard error sebesar 5\% atau $\sigma=0,05$ maka apabila nilai Sig (2-tailed) yang muncul pada tabel $<0,05$ maka Ho ditolak dan Ha diterima. Nilai Sig pada Gambar 7 menunjukan bahwa antara proses pemasangan snap ring sebelum adanya mesin press pneumatik untuk pemasangan snap ring dibanding dengan sesudah adanya mesin press pneumatik untuk pemasangan snap ring terjadi perubahan yang signifikan sehingga Ha diterima yang artinya bahwa proses pemasangan snap ring sesudah adanya mesin tersebut berpengaruh pada penurunan cycle time di assembling transmission line.

\subsection{Perhitungan Pengurangan Cycle time}

Rata rata data pengujian cycle time sebelum dilakukan improvement adalah 98,015 detik. Rata rata data pengujian cycle time setelah dilakukan improvement adalah 94,6 detik. Berikut adalah perhitungan pengurangan cycle time dan presentase pengurangan cycle time. Gambar 8 merupakan diagram pengurangan cycle time pada assembling transmission FF line. Pengurangan cycle time sebanyak 3,415 [detik] (Pers. 1) dengan presentase pengurangan sebesar 3,48\% (Pers. 2).

Pengurangan cycle time $=$ cycle time sebelum - cycle time sesudah

Presentase pengurangan cycle time $=\frac{\text { cycle time sebelum }- \text { cycle time } \text { sesudah }}{\text { cycle time } \text { sebelum }} \times 100 \%$

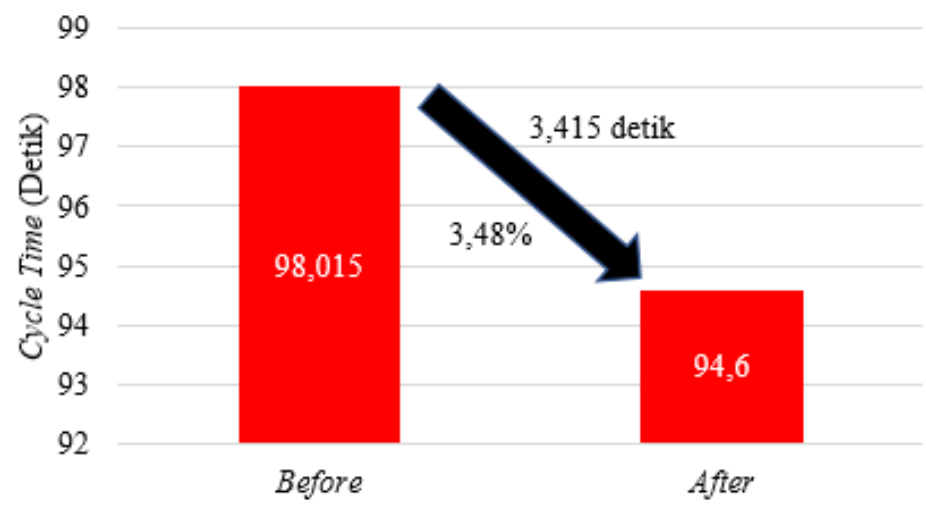

Gambar 8. Diagram Pengurangan Cycle time

\section{Kesimpulan}

Penelitian berhasil membuat rancang bangun mesin press pneumatik semi otomatis berbasis PLC untuk pemasangan snap ring pada input shaft gear yang dapat mengurangi cycle time pada assembling transmission FF di PT Akhasi Wahana Indonesia. Pengujian dilakukan sebanyak 30 kali pada tekanan 0,4 [MPa]. Sebelum adanya mesin press pneumatik semi otomatis berbasis PLC untuk pemasangan snap ring, cycle time pada assembling transmission FF adalah 98,015 detik. Setelah adanya mesin tersebut, cycle time pada assembling transmission FF menjadi 94,6 detik. Berdasarkan data tersebut yaitu sebelum dan setelah adanya mesin terdapat perbedaan cycle time, perbedaanya sebanyak 3,4 detik dengan persentase pengurangan sebesar $3,48 \%$. 
Timotius Anggit Kristiawan dkk /Jurnal Rekayasa Mesin

p-ISSN: 1411-6863, e-ISSN: 2540-7678 Vol.16|No.1|39-47|April|2021

\section{Daftar Pustaka}

[1] Triwulandari, S.D., Dedy, S., Dorina, H., Peluang dan Tantangan Industri Komponen Otomotif Indonesia. Jurnal Elektronik Unipdu. 2012; 1(2).

[2] Albertus, A. Pentingnya Kolaborasi Inovasi Perguruan Tinggi dengan Indsutri. https://edukasi.kompas.com/read/ 2020/10/16/081247371/pentingnya-kolaborasi-inovasi-perguruan-tinggi-dengan-industri?page=all. Kompas.com; 2020 (diakses pada tanggal 16 April 2021).

[3] Mulyadi., Sistem Perencanaan dan Pengendalian Manajemen: Sistem Pelipatganda Kinerja Perusahaan. Jakarta: Salemba Empat; 2007.

[4] Jaka, P., Abdul Haris, H.A., Perancangan Mesin Secara Ergonomi untuk Meningkatkan kapasitas produksi di UKM Mabel. Seminar Nasional Sains dan Teknologi Terapan IV (SNTEKPAN IV); 26 Oktober 2016; Surabaya, Indonesia. p. B 1-8.

[5] Wavhal, S., Mahadik, S., Angre, A., Shedge , U. K., \& Kashikar, A., A Review on Optimization of Cycle time by Using Various Techniques. International Journal of Engineering Development and Research (IJEDR). 2017; 5(1): p.723 - 725 .

[6] Ismail, F., Tri, W., Peningkatan Produktivitas menggunakan Metode Line Balancing pada Proses Pengemasan di PT.XYZ. Journal Industrial Manufacturing. 2018; 3(1): p. 57-63.

[7] Dutt, K., Analytical Description of Pneumatic System. International Journal of Scientific \& Engineering Research. 2013; 4(9).

[8] Setiawan, B., Rasma., Rancang Bangun Mesin Press Briket dari Bahan Serbuk Kayu Sistem Pneumatik Menggunakan 5 Tabung Percetak. Jurnal Program Studi Teknik Mesin UM Metro, 2019; 8(2): p. 135-142.

[9] Hudallah, N., Rancang Bangun Sistem Pneumatis Untuk Pengembangan Modul-Modul Gerak Otomatis sebagai Media Pembelajaran. Jurnal Teknik Elektro. 2010; 2(1).

[10] Rooney, J. J., \& Heuvel, L. N., Root Cause Analysis for Beginners. Quality Progress; 2004.

[11] Doggett, A. M., Root Cause Analysis a Framework for Tool Selection. Quality Management Journal. 2005; 12(04).

[12] Vorley, G., Mini Guide to Root Cause Analysis. Quality Management Training Limited; 2008.

[13] Kadirun, Hasanuddin, Aryanto., Penerapan Sistem Stop Sign pada Pertigaan Jalan Berbasis Sensor Photoelectric Studi Kasus pada PT. Chevron Pacific Indonesia. Jurnal Fasilkom. 2016; 5(2).

[14] Chriestie E.J.C. Mountolalu., Yohanes A.R. Langi., Pengaruh Pelatihan Dasar Komputer dan Teknoligo Informasi bagi Guru-Guru dengan Uji-T Berpasangan (Paired sample T-Test). Jurnal Matematika dan Aplikasi deCartesiaN. 2018; 7(1): p. 44-46.

[15] Machali, I., Statistik itu Mudah, Menggunakan SPSS Sebagai Alat Bantu Statistik. Yogyakarta: Ladang Kata; 2015. 